\title{
Individual Income Tax Revenue and Its Determinants: A Case Study in Vietnam
}

\author{
Than Thanh Son, Nguyen Huu Cung*
}

Hanoi University of Industry, Vietnam

Copyright $(2019$ by authors, all rights reserved. Authors agree that this article remains permanently open access under the terms of the Creative Commons Attribution License 4.0 International License

\begin{abstract}
Individual income tax revenue accounts for a high proportion of Vietnam's total tax revenues. The purpose of the article is to study the factors affecting individual income tax revenue in Vietnam. The findings show that there are three factors, which have the strongest impact on the individual income tax revenue including GDP at current prices, individual income tax burden and inflation. Based on the empirical results, the article proposes some policy implications that can increase the individual income tax revenue without exceeding the people's endurance.
\end{abstract}

Keywords Tax, Tax Revenue, Individual Income, Individual Income Tax, Vietnam

\section{Introduction}

The individual income tax was applied hundreds of years ago, in present it has become one of the most commonly taxes was applied in most countries in the world. According to Hua Liu et al. (2012) and Nguyen Huu Cung et al. (2013), the application of individual income tax has appeared in two directions. Firstly, if the individual income tax burden is reasonable then may both stimulate economic growth and increase the state budget revenue. Secondly, if the individual income tax burden is excessive then will have a negative impact, and vice versa. In Vietnam, this tax has been applying for many years, but from 2008 and earlier applied the individual income tax ordinance, unsecured perfection level, executable apparatus not yet been professional, economic transactions mainly be paid in cash, tax evasion and some other reasons, therefore the individual income tax revenues was lost. After moved from the Ordinance to the Law, perfection and professionalism be improved, the types of income that be not previously included in the Ordinance then be adjusted in the Law, from which the revenue was be increased quickly.

A empirical study built a simple model with an independent variable to be GDP at current prices affecting
Vietnam's individual income tax revenue during 2002 2011, the results showed that when GDP at current price is an increase of 1 billion VND, the individual income tax revenue will increase to 0.020162 billion VND (Nguyen Huu Cung et al., 2013). Another empirical study built a model with two independent variables to be GDP per capita and time trend affecting the individual income tax per capita of Vietnam in the period of 2002 - 2011. The results that GDP per capita increased by 1 unit, the individual income tax per capita increased from 0.011970325 units to 0.021879675 units (Nguyen Huu Cung and Liu Hua, 2014). Gerardo Ángeles Castro and Diana Berenice Ramírez Camarillo (2014) researched the determinants of tax revenue in OECD countries over the period 2001 - 2011, the results that gross domestic product per capita, the industrial sector, and civil liberties have positive impact on the dependent variable, while the agricultural sector and the share of foreign direct investment in gross fixed capital formation have negative impact [4]. Irena Palić et al. (2017) researched the determinants of individual income taxation in Croatia, the cointegration analysis is conducted using monthly data from January 2008 to February 2016, the results of the research show a statistically significant negative impact of economic conditions and statistically significant positive impact of average monthly wage and number of taxpayers on personal income taxation in long run [5]. Castro and Camarillo (2014) concluded that determinants of tax revenues in OECD differ among high-income and middle-income countries. High-income countries with high GDP per capita, low share of FDI, and robust industrial sector have higher tax revenues (Castro and Camarillo, 2014). Velaj and Prendi (2014) conducted regression analysis in order to determine what impacts tax revenues in Albania. They considered several variables: GDP, inflation, income tax, unemployment and imports. Their analysis has shown positive correlation between tax revenues and with GDP growth, inflation and imports, while unemployment has shown negative correlation (Velaj and Prendi, 2014). Karagoz (2013) used regression analysis in order to investigate determinants of tax revenues in Turkey. Mentioned research showed that 
agricultural and industrial share in GDP, foreign debt stock, monetization rate and urbanization rate have a significant impact on total tax revenues (Karagoz, 2013).

If the individual income tax burden is increased over time then can create an increase of tax revenue. Vice versa, excessive tax burden will reduce individual income tax revenues. A research result has shown that the annual average individual income tax burden of Vietnam in the period of 2002-2008 was nearly $0.57 \%$ and lower than China, but when the Ordinance was upgraded to the Law, the revenue is increasing more and more and the tax burden of Vietnam to be higher than China in 2010 - 2011 period (Nguyen Huu Cung et al., 2013). This research also found, the excess burden of Vietnam's individual income tax burden seems to exist, due to the taxable income and family allowances did not keep the volatility of macroeconomic indicators, therefore, the individual income tax law was amended in the direction of raising the taxable level and family allowances in 2013. James R. Hines Jr. (2007) said that the excess burden of taxation is the efficiency cost, or deadweight loss, associated with taxation, or Alan J. Auerbach et al (2001) also said that tax-induced reductions in economic efficiency are known as deadweight losses or the excess burdens of taxation, the latter signifying the added cost to taxpayers and society of raising revenue through taxes that distort economic decisions. In the report of Robert Carroll (2009) estimated that the economic cost of higher tax rates, what economists often refer to as the "excess burden" or "deadweight loss" of taxes. These studies have shown that the economic cost of lost without any subject in the economy such as the State, businesses or consumers be enjoyed by the impact of taxation.

However, until now, the scale and quality research about factors affecting the individual income tax revenue in Vietnam is still considered as a scarcity. In Vietnam, researchers mainly use descriptive statistical methods to analyze tax revenue, tax burden and compare the burden rate between Vietnam and other countries in area. In addition, the main findings in the articles about individual income tax reform, individual income tax collection management, solutions to improve individual income tax revenue and other issues. This is still a question that requires serious studies from economic researchers. The purpose of this article is to answer the questions: How many factors affect individual income tax revenue? Which factor is the most important?

\section{Theoretical Framework}

\subsection{Definition, Characteristics and Role}

A topic that scholars are very interested to be individual income tax. Moreover, this is also a tax that is highly appreciated by most countries in the world due to the large revenues of the state budget. In the condition that the economy of the countries is constantly growing, the income of each individual is increasing, the importance of this tax is raised. So, what is the individual income tax? According to the Wikipedia's definition: "An income tax is a tax imposed on individuals or entities (taxpayers) that varies with respective income or profits (taxable income). Income tax generally is computed as the product of a tax rate times taxable income. Taxation rates may vary by type or characteristics of the taxpayer". According to the Business Dictionary's definition: "Tax paid on one's personal income as distinct from the tax paid on the firm's earnings. In an incorporated firm, the owners (shareholders) pay taxes on both their income (salary or dividend from the firm) firm's income (profits). In partnerships and sole-ownerships, the tax is paid only once on the firm's profits". These concepts show that income tax laws apply to individuals or businesses. For businesses' income, Governments adjust by corporate income tax law. For individuals' income, Governments adjust by individual income tax law. According to the Urban Institute's definition: "The individual income tax (or personal income tax) is levied on the wages, salaries, dividends, interest, and other income a person earns throughout the year". Thus, the individual income tax is a tax that is collected on the income of individuals to mobilize a part of their income to the state budget. In addition, the state can use this tax to regulate the macro economy through equal mobilization among individuals in society, and through tax incentives to encourage accumulation and investment of individuals and improving residential life.

Since Law on individual income tax was applied so far with many different names, whether in a closed or open economy, even in the trend of economic globalization, the authors think that the individual income tax has the most common characteristics such as: Firstly, individual income tax is a direct tax, directly levied on income generated by each time or by a certain period of time, so the taxable subject of this tax is the income of the individuals. Secondly, the individual income tax is not stable, because the income of individuals changes over time, income sources are increasingly diverse, especially for developing countries belonging to the high growth group, moreover difficult tax collection and high collection management costs in most developing countries paying in cash. Thirdly, the scope of adjustment of the individual income tax is a relatively large to be all taxable incomes whether generated from business or investment or labor. Fourthly, the laws adjust the individual income tax including national law and international law, the individuals' income arises inside or outside the territory of a country, taxpayers may be local residents or foreigners, personal income tax can be adjusted by double taxation agreement.

The individual income tax is an important tax in the tax system of countries. The purpose of countries applies the individual income tax to promote its available roles. Thus, what are the roles of the individual income tax? Firstly, 
revenue from the individual income tax accounts for a large proportion of the total state budget revenue of each country. The individual income tax is calculated with a wide range, the ability to generate revenue for the state budget is very large. The individual income tax has a direct impact on the income of the people that the people of any country want to have higher and higher income to improve their material and spiritual life. The individual income tax always has a rapid increase along with an increase in per capita income. Secondly, contribute to social justice. Implementation of social justice is one of the important roles of the individual income tax through schedule of proportional and progressive tax rates. Thirdly, regulate income, consumption and savings. Because the individual income tax directly regulates individuals' income, its burden exceeds the tolerance of the people, on the one hand direct impact on savings, on the other hand a decrease in solvency of individuals. Consequently, demand for goods and services will be reduced, which will affect production. Fourthly, contribute to overcome some disadvantages of other taxes. The disadvantage of some indirect taxes such as value-added tax and special consumption tax is regressive tax and affecting the poor people more than the rich people, because when consuming the same amount of goods and services do not distinguish the rich or poor people are equally taxable. If calculating the individual income tax according to the progressive tax schedule will overcome this disadvantage.

\subsection{The Vietnamese Individual Income Tax: An overview}

\subsubsection{Reform Process}

Vietnam applied to law on individual income tax rather late compared with many countries, especially the developed countries. Nguyen and Liu (2014) said that Vietnam's tax system has undergone many reforms, after each reform is an improvement of tax laws. Associated with the tax reform step 1 is the formation of the individual income tax ordinance on high-income earners issued on 12/27/1990 (The State Council of Vietnam, 1991). The period of the tax reform step 2 (1996 - 2000), this ordinance was amended and supplemented twice as early as 1997 (The Standing Committee of Vietnam National Assembly, 1997) and in mid-1999 (The Standing Committee of Vietnam National Assembly, 1999). The period of tax administration reform (2001-2005), this ordinance continued to be amended and supplemented with some articles such as tax rate, an increase of the starting level of taxable income, especially to expand the gap of the level of taxable income in each tax rate (The Standing Committee of Vietnam National Assembly, 2004). In this period, Vietnam is one of the countries with the highest economic growth rate in the world, an increase in per capita income, a diversity of income sources, and many individuals with high income. Stemming from these reasons, the Law on individual income tax was established to replace the income tax ordinance on high-income earners and passed on 9/21/2007 and came into effect on 1/1/2009 (Vietnam National Assembly, 2007). The upgrade from the Ordinance to Law has been consistent with the development trend of the economy and social awareness about the responsibility of citizens for paying personal income tax. However, due to the continuous development of Vietnam's economy and society, the individual income tax was amended and supplemented in 2012 (Vietnam National Assembly, 2012), came into effect on 1/1/2014 (some articles apply from July 1,2013).

\subsubsection{Individual Income Tax Revenue}

The adjustment of Vietnam's individual income tax law not only benefits taxpayers but also increases tax revenue over the years. In 2002, revenue from income tax for high-income earners was only VND 2,338 billion accounting for $2.31 \%$ of total tax revenue, about $1.89 \%$ of total state budget revenue, and average annual in the period of 2002 - 2008 only reached VND 5,511 billion, the average annual growth rate was $31 \%$. After applying the Law since 2009, the revenue of this tax has increased rapidly in the direction of next year higher than the previous year. Average annual in the period of $2009-2016$, the individual income tax revenue reached VND 42,548 billion, the average annual growth rate was 25\% (Fig.1). The reasons that Vietnam belongs to a group of countries with high economic growth over the years, at the same time a continuous increase in GDP at current prices and per capita income and tax burden rate. However, besides factors affecting individual income tax revenue in a positive sign, there are also some negative factors, such as an increase of inflation, decreasing growth rate of per capita income. 
(Unit: Billion VND)



Source: Ministry of Finance, Vietnam

Figure 1. Individual Income Tax Revenue in Vietnam during the Period 2002-2016

\subsection{Determinants}

\subsubsection{GDP at Current Prices}

One of the most important factors affects the increase or decrease of tax revenue is GDP at current prices, which is a proportional relationship. Revenue of each tax also moves according to this trend. When studying the determinants of personal income tax revenue during 2002 - 2011, Nguyen Huu Cung et al. (2013) found that there are many factors affecting personal income, in which GDP at current prices is the most important factor. Thus, under the condition that other factors remain constant, if GDP at current prices increases, personal income tax revenue will also increase. In fact, in Vietnam, the growth rate of GDP is relatively high in previous years and therefore the per capita income also increase rapidly. Thus, the income of a large part of the population not only responses the quality of life of individuals and families better and better, but also ensures a surplus of financial resources to save or reinvest. This means that in many cases their income is subject to personal income tax. In addition, due to the rapid development of Vietnam's economy, many new industries have been generated, from which people have more opportunities to seek and improve their incomes. At the same time, during the period of application of high income tax ordinances and personal income tax laws, the terms of deduction for taxpayers and the family allowances are adjusted according to the change of actual spending demand and the increase in consumer price indexes, the result is a rapidly increasing number of people who have to pay personal income tax and the number of people previously had to pay personal income tax at a low tax rate is now subject to higher tariffs. We can temporarily conclude that, in recent years in Vietnam, personal income tax revenue has been increasing mainly due to economic growth factors and per capita income, this means that the relationship between GDP at current prices and personal income tax revenue is a positive sign (Fig.2).

\subsubsection{GDP at Current Prices}

Another important factor influencing the increase or decrease in revenue of each tax is the tax burden. In the case that other factors remain constant, if the tax burden increases, the revenue of each tax will increase. In Vietnam, in the period of 2002-2008, the value of tax revenue for high-income earners accounted for a low proportion of the total tax revenue, the total personal income tax revenue of this period reached VND 38,578 billion, an average of VND 5,511 billion annually, the rate of tax burden per year was $0.57 \%$. In the period of $2009-2016$, because the tax ordinance was replaced by the tax law, the tax rate increased by the progressive method with the lowest level of $5 \%$ corresponding to level 1 and the highest is $35 \%$ corresponding to level 7, many sources of additional income were adjusted in the law, the taxable income and the family circumstance deduction were adjusted, so the total revenue from this tax increased rapidly, averagely reaching VND 42548 billion per year, so the rate of the average annual burden was $1.32 \%$ and higher than the previous period. Including the period 2002 - 2016, personal income tax revenue increased from VND 2238 billion in 2002 to VND 65239 billion in 2016, the burden rate of this tax also increased over time from $0.44 \%$ in 2002 to $1,45 \%$ in 2016. From the results of this analysis, we can conclude that personal income tax revenue and personal income tax burden are a positive sign (Fig.3). 
(Unit: Billion VND, \%)

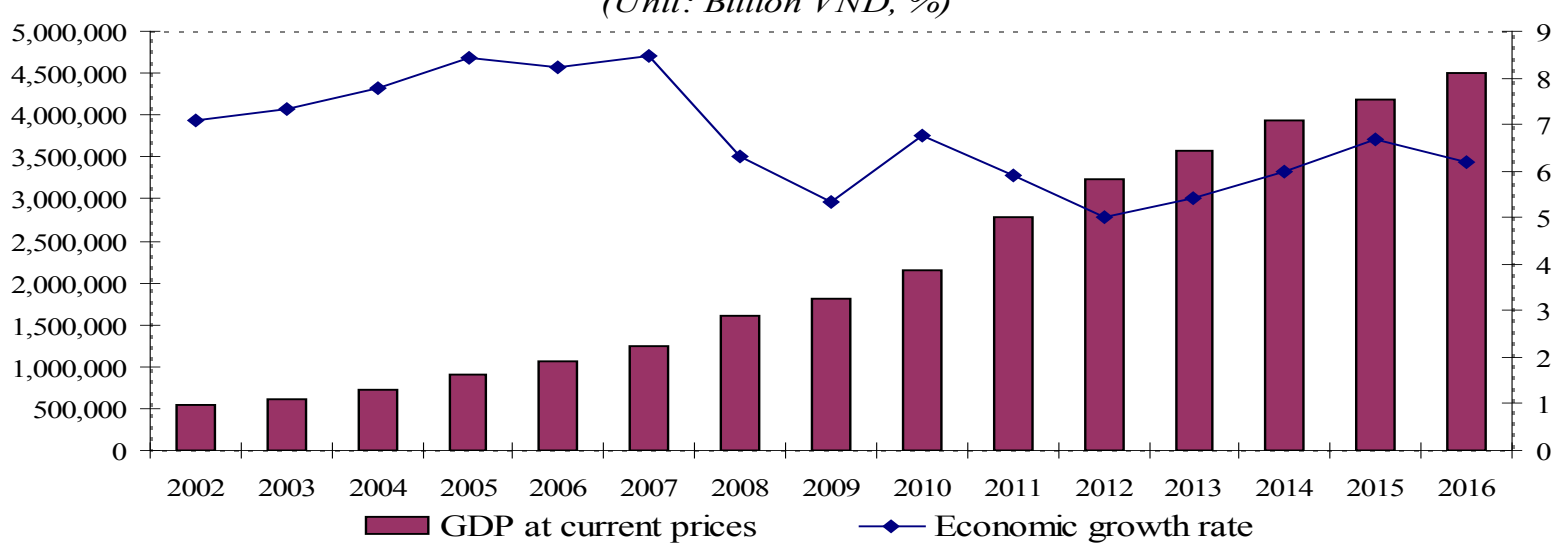

Source: General Statistics Office of Vietnam

Figure 2. GDP at current prices and Economic growth rate in Vietnam

(Unit: Billion VND, \%

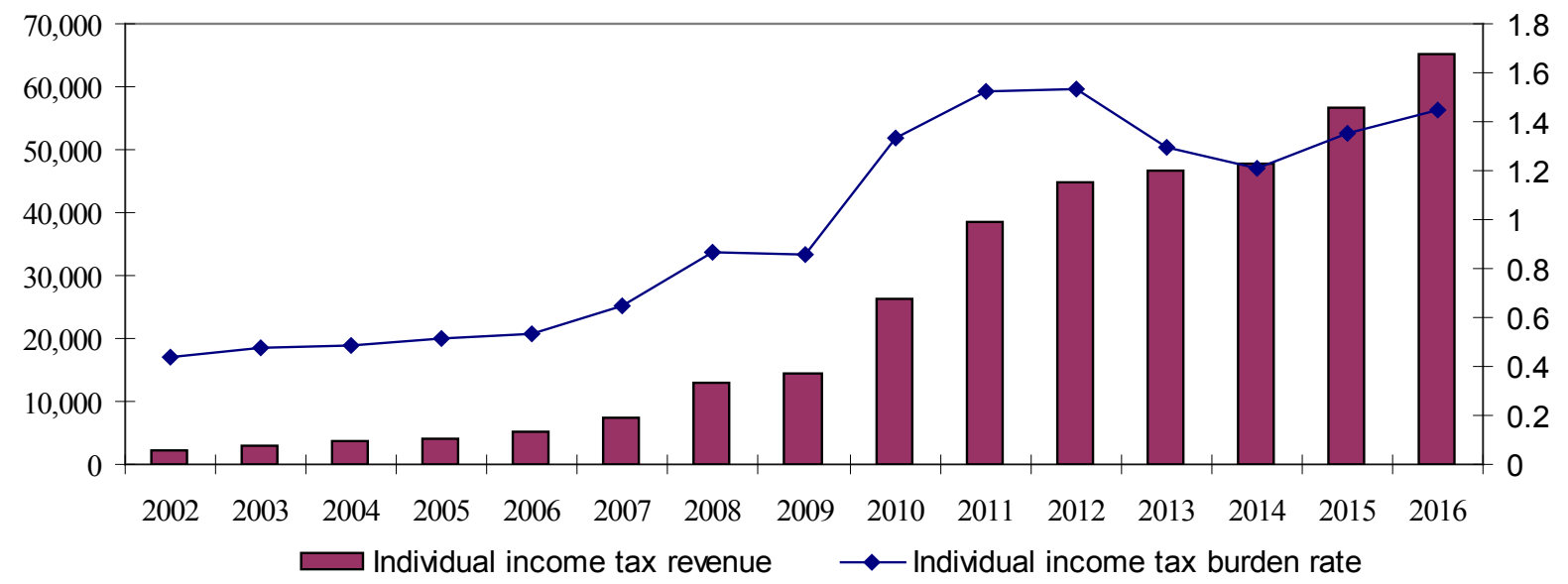

Source: Ministry of Finance and General Statistics Office of Vietnam and The author's calculations

Figure 3. Individual income tax revenue and Individual Income Tax Burden Rate in Vietnam

\subsubsection{Inflation Rate}

The fluctuation of CPI may affect tax revenue. The results of the study by Hizir Sofyan et al. (2017) pointed out that there is a relationship between tax revenue and inflation in Banda Aceh, Indonesia. Therefore, the relationship between personal income tax revenue and inflation rate can also be a negative sign or a positive sign depending on the region or country. Theoretically, the inflation rate increases over time and exceeds the control level of the countries expressed by the price index increases, production costs and consumption increases, the inadequate rate of increase in income, resulting in goods that are difficult to consume, many businesses go bankrupt or temporarily stop production or maintain production, rising unemployment rates, declining economic growth rates, average income declining per capita, from which revenue of taxes decreased and personal income tax revenue also decreased according to that trend, and vice versa. Figure 4 shows the trend of the relationship between personal income tax revenue and inflation rate in Vietnam as follows: Firstly, before the economic crisis (2007), the inflation rate in moderate levels and personal income tax revenues steadily increased between 2002 and 2006. Secondly, during the economic crisis period (2007 - 2011), high inflation rates and personal income tax revenues also increased but with lower speed. Thirdly, in the period of economic recovery (2012 - 2016), due to the good control of inflation rate and strong downward trend, economic growth tends to increase, income per capita is improved, personal income tax revenue increased. Thus, the relationship between personal income tax revenue and inflation rate is a negative sign, the fact in Vietnam is consistent with economic theory. 
(Unit: Billion VND, \%)

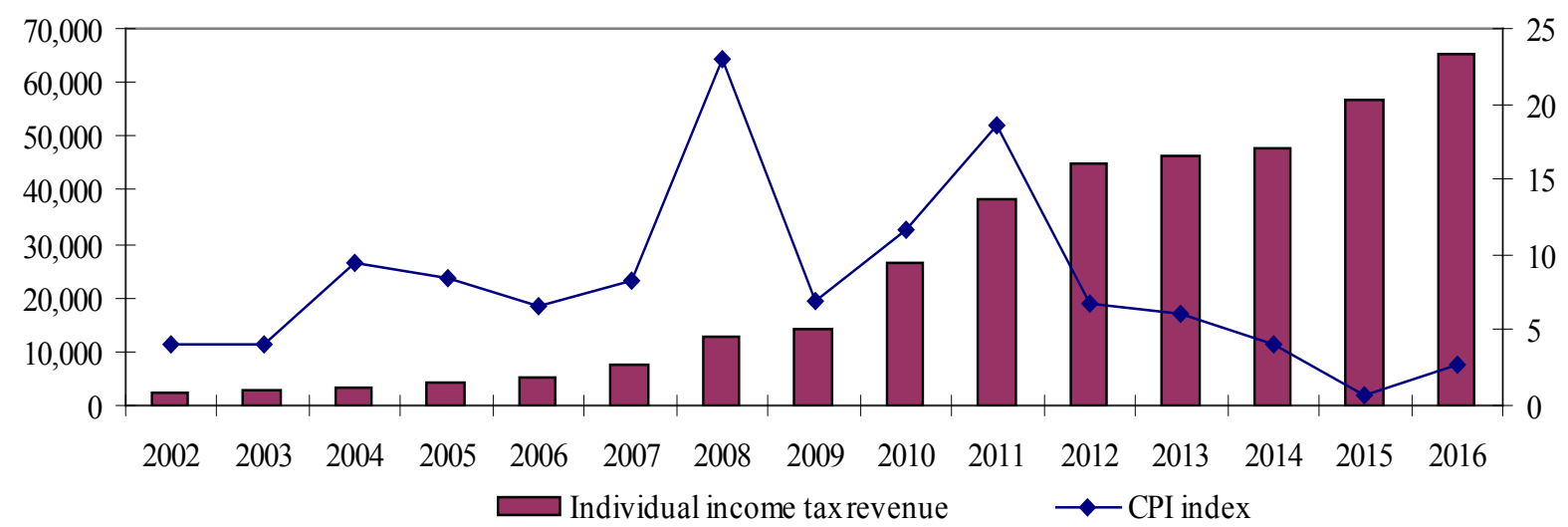

Source: Ministry of Finance and General Statistics Office of Vietnam

Figure 4. Individual income tax revenue and CPI index in Vietnam

\section{Data and Method}

The individual income tax revenue is affected by many different factors. The impact of each factor on revenue of this tax can be a negative or a positive sign. The article uses empirical method to determine the impact level of factors on Vietnam's individual income tax revenue. The time period that the authors use by 15 years (from 2002 to 2016). Data on individual income tax revenue, GDP at current prices, tax burden rate, inflation rate are used corresponding to the above time sequence. Data sources are used from the portal of the Ministry of Finance and the General Statistics Office of Vietnam.

The model is based on the assumption that the individual income tax revenue will be determined by factors: GDP at current prices, tax burdens, inflation rates. Under this assumption, the authors have performed regressions of 3 models. First, Model 1 is estimated to judge the impact of GDP at current prices on Vietnam's individual income tax revenue. Second, Model 2 is added one independent variable of the individual income tax burden (the ratio between individual income tax revenue and GDP at current prices), thereby estimating the impact of GDP at current prices and tax burden rate on Vietnam's individual income tax revenue. Third, Model 3 is added one independent variable of inflation rate, thereby estimating the impact of GDP at current prices, individual income tax burden and inflation rate on Vietnam's individual income tax revenue.

$$
\begin{aligned}
& \text { Model 1: } \operatorname{TAX}_{t}=\hat{\beta}_{1}+\hat{\beta}_{2} \mathrm{GDP}_{t}+\mu_{t} \\
& \text { Model 2: } \operatorname{TAX}_{t}=\hat{\beta}_{1}+\hat{\beta}_{2} \mathrm{GDP}_{t}+\hat{\beta}_{3} \frac{T \mathrm{AX}_{t}}{\mathrm{GDP}_{t}}+\mu_{t} \\
& \text { Model 3: } \mathrm{TAX}_{t}=\hat{\beta}_{1}+\hat{\beta}_{2} \mathrm{GDP}_{t}+\hat{\beta}_{3} \frac{T \mathrm{TX}_{t}}{\mathrm{GDP}_{t}}+\hat{\beta}_{4} \mathrm{INPL}_{t}+\mu_{t}
\end{aligned}
$$

In which, TAX is individual income tax revenue (billion VND), GDP is gross domestic product at current prices (billion VND), TAX/GDP is the ratio between individual income tax revenue and GDP at current prices, INPL is inflation rate.

After the regression of the above three models, the results show that the model 3 is the most suitable compared to the other two models. But only the value of Durbin-Watson test shows that this model has an auto-correlation phenomenon grade 1 . The authors will use the general differential equation to remedy this violation.

$$
\begin{aligned}
& \left(\operatorname{TAX}_{t}-\hat{\rho} T A X_{t-1}\right)=\hat{\beta}_{0}(1-\hat{\rho})+\hat{\beta}_{1}\left(G D P_{\mathrm{t}}-\hat{\rho} G D P_{(t-1)}\right)+\hat{\beta}_{2}\left(T A X / G D P_{t}-\right. \\
& \left.-\hat{\rho} T A X / G D P_{(t-1)}\right)+\hat{\beta}_{3}\left(I N P L_{t}-\hat{\rho} I N P L_{(t-1)}\right)+\left(\mu_{t}-\hat{\rho} \mu_{t-1}\right)
\end{aligned}
$$

The authors will use the two following auxiliary regressions to test the auto-correlation phenomenon grade 1 :

The model has not the block coefficient:

$$
\varepsilon_{t}=a_{1} \varepsilon_{t-1}+v_{t}
$$


The model has the block coefficient:

$$
\varepsilon_{t}=a_{0}+a_{1} \varepsilon_{t-1}+v_{t}
$$

After regression for Model (5) and Model (6), the estimated value of the correlation coefficient grade 1 is $\hat{\rho} \cong 0.26$, to substitute into Model (4). From which, Model (4) has the following form:

$$
\begin{aligned}
& \left(\operatorname{TAX}_{t}-0.26 T A X_{t-1}\right)=\hat{\beta}_{0}(1-0.26)+\hat{\beta}_{1}\left(G D P_{\mathrm{t}}-0.26 G D P_{(t-1)}\right)+\hat{\beta}_{2}\left(T A X / G D P_{t}-0.26 T A X / G D P_{(t-1)}\right)+ \\
& +\hat{\beta}_{3}\left(I N P L_{t}-0.26 I N P L_{(t-1)}\right)+\left(\mu_{t}-0.26 \mu_{t-1}\right)
\end{aligned}
$$

\section{Results and Discussion}

With the simplest form of the regression equation, the authors will regress the relationship between individual income tax revenue and GDP at current prices. After performing the operations, the regression results are in Table 1 below:

Table 1. The regression results of Model (1)

\begin{tabular}{ccccc}
\hline Variable & Coefficient & Std. Error & t-Statistic & Prob. \\
\hline C & -9536.030 & 1572.875 & -6.062803 & 0.0000 \\
\hline GDP & 0.015860 & 0.000610 & 25.99661 & 0.0000 \\
\hline R-squared: & 0.981127 & \multicolumn{2}{c}{ Durbin-Watson stat: } & 0.974708 \\
\hline Adjusted R-squared: & 0.979675 & \multicolumn{2}{c}{ F-statistic: } & 675.8237 \\
\hline
\end{tabular}

Table 2. The regression results of Model (2)

\begin{tabular}{ccccc}
\hline Variable & Coefficient & Std. Error & t-Statistic & Prob. \\
\hline C & -12027.93 & 2138.828 & -5.623609 & 0.0001 \\
\hline GDP & 0.014021 & 0.001275 & 11.00016 & 0.0000 \\
\hline TAX/GDP & 6743.618 & 4169.775 & 1.617262 & 0.1318 \\
\hline R-squared: & 0.984505 & Durbin-Watson stat: & 0.689754 \\
\hline Adjusted R-squared: & 0.981922 & \multicolumn{2}{c}{ F-statistic: } & 381.2126 \\
\hline
\end{tabular}

In table 1 , for GDP at current prices variable, $p \_v a l u e=$ $0.0000<\alpha=5 \%$ is statistically significant. Due to $\hat{\beta}_{0}=-9536.030$, the sign of the block coefficient is a negative sign $\left(\hat{\beta}_{0}=-9536.030\right), \mathrm{R}^{2}=0.981127$ and F-statistic $=675.8237$ are too big, which is inconsistent with economic theory. The $\hat{\beta}_{0}=-9536.030$ shows that the value of GDP at current prices is zero, the Government will not collect the state budget, including individual income tax. However, the value $d$ of Durbin-Watson test by 0.974708 , meanwhile the significance level $\alpha=5 \%=0.05$, the sample numbers $\mathrm{n}=15$, number of independent variables in the model $\mathrm{k}^{\prime}=1$, inferred $d_{L}=1,077$ and $d_{U}=$ 1,361. Due to $d<d_{U}$, Model (1) has an auto-correlation phenomenon grade 1. From this result, it is necessary to add independent variables, because the individual income tax revenue is not only affected by the increase in GDP at current prices but also by some other important factors, for example, in the short-term, if the tax burden rate (TAX/GDP) is higher than the tax revenue is greater.

The authors regress the relationship between a dependent variable (individual income tax revenue) and two independent variables (GDP at current prices and individual income tax burden. After performing the operations, the regression results are in Table 2 . With the above regression results show, $p_{-}$value of GDP at current prices $=0,0000<\alpha=5 \%$ and the values of the t-Statistic test of GDP and TAX/GDP and F-statistic $=29.66880$ are large, all are statistically significant. At the same time, the slope of $\hat{\beta}_{0}=-12027.93$ is a negative sign, $\hat{\beta}_{1}=0.014021$ and $\hat{\beta}_{2}=6743.618$ are a positive sign, which is in accordance with economic theory. However, $p$ value of TAX/GDP $=0.1318>\alpha=5 \%$, means that the impact of individual income tax burden on the individual income tax revenue is not great. Moreover, $d$ value of the Durbin-Watson test is 0.689754 , while at the significance level $\alpha=5 \%$, the number of sample size is $\mathrm{n}=15$, the number of independent variables in the model is $\mathrm{k}{ }^{\prime}=2$, inferred $d_{L}=0,946$ and $d_{U}=1,543$, due to $\mathrm{d}<d_{U}$, the model has an auto-correlation phenomenon grade 1 . From this analysis, the authors judge that Model (2) has omitted the independent variable, necessarily adding an independent variable - the inflation rate. 
Table 3. The regression results of Model (3)

\begin{tabular}{ccccc}
\hline Variable & Coefficient & Std. Error & t-Statistic & Prob. \\
\hline C & -11053.39 & 2088.261 & -5.293110 & 0.0003 \\
\hline GDP & 0.012356 & 0.001566 & 7.891628 & 0.0000 \\
\hline TAXGDP & 11803.15 & 4973.339 & 2.373284 & 0.0369 \\
\hline INPL & -274.9115 & 167.4636 & -1.641620 & 0.1289 \\
\hline R-squared: & 0.987554 & \multicolumn{2}{c}{ Durbin-Watson stat: } & 1.283873 \\
\hline Adjusted R-squared: & 0.984159 & \multicolumn{2}{c}{ F-statistic: } & 265.1462 \\
\hline
\end{tabular}

Table 4. The regression results of Model (8)

\begin{tabular}{ccccc}
\hline Variable & Coefficient & Std. Error & t-Statistic & Prob. \\
\hline C & -13619.76 & 2589.976 & -5.258645 & 0.0004 \\
\hline GDP+0.26*GDP(-1) & 0.011990 & 0.001570 & 7.638849 & 0.0000 \\
\hline TAXGDP+0.26*TAXGDP(-1) & 12912.11 & 4826.825 & 2.675074 & 0.0233 \\
\hline INPL+0.26*INPL(-1) & -362.3111 & 187.0760 & -1.936705 & 0.0815 \\
\hline R-squared: & 0.990694 & Durbin-Watson stat: & 1.836906 \\
\hline Adjusted R-squared: & 0.987902 & \multicolumn{2}{c}{ F-statistic: } & 354.8543 \\
\hline
\end{tabular}

The authors will continue to regress the relationship between individual income tax revenue and GDP at current prices, individual income tax burden, and inflation rate. In Table 3, the regression results show that the t-Statistic test, p_value, $\mathrm{R}^{2}, \mathrm{~F}$-statistic and the sign of the slopes are statistically significant. However, the $d$ value of the Durbin-Watson test is $1.283873, \alpha=5 \%, \mathrm{n}=15, \mathrm{k}^{\prime}=3$, inferred $d_{L}=0.814$ and $d_{U}=1.750$, due to $\mathrm{d}<d_{U}$, the model has an auto-correlation phenomenon grade 1 . To overcome the auto-correlation phenomenon, the authors will regress the general differential equation (Model 7) and the regression results are in Table 4.

According to the regression results of Model (7), the sign of $\hat{\beta}_{0}, \hat{\beta}_{1}, \hat{\beta}_{2} \quad \hat{\beta}_{3}$ and $\hat{\beta}_{4}$ are in accordance with economic theory. The $d_{-}$value of Durbin-Watson test by 1.836906, meanwhile the significance level $\alpha=5 \%$, the sample numbers $\mathrm{n}=15$, the number of independent variables in the model $\mathrm{k}^{\prime}=3$, inferred $d_{L}=0.814$ and $d_{U}=$ 1.750. Due to $d>d_{U}$, so Model (7) do not have an auto-correlation phenomenon. With $\alpha=5 \%=0.05$, p_value of GDP and TAX/GDP is so small, this shows that the effect of GDP at current prices and individual income tax burden on individual income tax revenue is too strong but the effect of inflation rate is not strong. The regression results also show, $\mathrm{R}^{2}=0.990694$, means that the change of the independent variables explains $99.0694 \%$ of the change of the dependent variable. R2 and F-statistic are relatively large, so the regression model is suitable. After changing the variables, the block coefficient estimation of Model (7) is -13619.76 , from that the block coefficient estimation of Model (3) is $\hat{\beta}_{0}=[-13619.76 /(1-0,26)]=-18405.08$. The slope estimation of the original model is $\hat{\beta}_{1}=0.011990$, $\hat{\beta}_{2}=12912.11, \hat{\beta}_{3}=-362.3111$.
Thus, the authors performed to regress the relationship between individual income tax revenue and independent variables through three regression models. The regression results show that Model (3) is the most suitable compared to the other two models.

The case study of Vietnam shows a similarity to tax theory and practice in other countries. First, Vietnam's individual income tax contributes to equitable distribution of income and an increase in the state budget. Second, the ratio of individual income tax burden is higher, this tax revenue is greater in the short-term, but a gradual decrease in the long-term, a positive relationship. Third, GDP at current prices increases over time and the population growth rate is controlled, an increase in individual income tax revenue, a positive relationship. Fourth, the inflation rate is higher, the individual income tax revenue is lower, a negative relationship.

\section{Conclusions and Policy Implication}

In this article, the authors has discovered three factors affecting individual income tax revenue such as GDP at current prices, individual income tax burden, inflation rate. Based on $p_{-}$value, the findings also show that the impact level of GDP at current prices on individual income tax revenue is greater than individual income tax burden and inflation rate. This means that to increase individual income tax revenue need to increase GDP at current prices and at the same time controlling population growth rate. In Vietnam, how to increase GDP at current prices? The solutions are: flexible monetary policy and fiscal policy, lower interest rates, a breakthrough development of enterprises in both scale and quality, (especially private enterprises), a market expansion in both domestic and abroad, an adjustment of tax policies to encourage the 
development of businesses (especially small and medium enterprises, technology enterprises) and others.

\section{REFERENCES}

[1] Hua Liu et al. (2012). Analysis of Differences of The Personal Income Tax Regime between Vietnam and China. 2nd International Conference on Financial Management and Economics (Singapore), Vol.43, pp.231-237.

[2] Nguyen Huu Cung et al. (2013). Determinants of Revenue of Personal Income Tax in Vietnam. In Proc. of The 4th Int. Asia Conf. on Industrial Engineering and Management Innovation (IEMI'2013), Taiwan, 2013, pp. 126-130, ISBN: 978-3-642-40059-9.

[3] Nguyen Huu Cung and Liu Hua (2014). A Comparative Study on Individual Income Tax Burden of Vietnam and China. Business and Management Research, Vol. 3, No. 2, pp. 60-66.

[4] Gerardo Ángeles Castro and Diana Berenice Ramírez Camarillo (2014). Determinants of tax revenue in OECD countries over the period 2001-2011. Contaduría y Administración, Volume 59, Issue 3, pp. 35-59.

[5] Irena Palić at el (2017). Analysis of personal income taxation determinants in Croatia in long run: Evidence from Cointegration Analysis. Journal of contemporary issues in economics and business, Volume 63, Issue 3, pp. 12-18.

[6] Velaj and Prendi (2014). Tax revenue-The determinant factors-the case of Albania. European Scientific Journal. Special Edition Vol.1, 526-531. Retrieved from

[7] Karagoz, K. (2013) Determinants of tax revenue: Does sectorial composition matter? Journal of Finance, Accounting and Management, 4(2), 50-63.

[8] James R. Hines Jr. (2007), Excess Burden of Taxation, Working Paper Series, Product Number WP 2007-1.

[9] Alan J. Auerbach and James R. Hines Jr. (2001), Taxation and Economic Efficiency, NBER Working Paper No. 8181, March 2001.

[10] Robert Carroll (2009), The Excess Burden of Taxes and the Economic Cost of High Tax Rates, Tax Foundation, Special Report, No. 170.

[11] https://en.wikipedia.org/wiki/Income_tax

[12] http://www.businessdictionary.com/definition/personal-inc ome-tax.html

[13] https://www.urban.org/policy-centers/cross-center-initiativ es/state-and-local-finance-initiative/projects/state-and-local -backgrounders/individual-income-taxes

[14] Cung Huu Nguyen and Hua Liu (2014), A Comparative Study on Individual Income Tax Burden of Vietnam and China, Business and Management Research, Vol. 3, No. 2, pp. 60-66.

[15] The State Council of Vietnam. (1991). Ordinance on Personal Income Tax. Issued on 07/01/1991. (Vietnamese version)
[16] The Standing Committee of Vietnam National Assembly. (1997). Ordinance on Personal Income Tax (amendment and supplement). Issued on 02/06/1997. (Vietnamese version)

[17] The Standing Committee of Vietnam National Assembly. (1999). Ordinance on amending and supplementing a number of articles of the Ordinance on Income Tax on High Income Earners. No. 4/1999/PL-UBTVQH10, Issued on 06/30/1999. (Vietnamese version)

[18] The Standing Committee of Vietnam National Assembly. (2004). Ordinance on Personal Income Tax (amendment and supplement). No. 14/2004/PL-UBTVQH11, Issued on 03/24/2004. (Vietnamese version)

[19] Vietnam National Assembly. (2007). Law on Personal Income Tax. No. 04/2007/QH12, Issued on 11/21/2007. (Vietnamese version)

[20] Vietnam National Assembly. (2012). Law on Personal Income Tax (amendment and supplement). No. 26/2012/QH13, Issued on 11/22/2012. (Vietnamese version)

[21] Hizir Sofyan et al. (2017). Structure analysis of tax revenue and inflation rate in Banda Aceh using vector error correction model with multiple alpha. AIP Conference $\begin{array}{llll}\text { Proceedings } & 1905, & 050029 & \text { (2017); }\end{array}$ https://doi.org/10.1063/1.5012248 